L. Yu.Tomarovska, S. V. Baiurka, S. A. Karpushyna

National University of Pharmacy

\title{
Development of the methods for atomoxetine identification suitable for the chemical and toxicological analysis
}

The cases of acute and lethal poisonings by atomoxetine, an antidepressant, have been registered. Therefore, development of the available and reliable methods for its chemical and toxicological analysis is the topical issue.

Aim. To develop the conditions for atomoxetine detection in the presence of a number of its pharmacological and structural analogs when performing the general TLC-screening and identification of the antidepressant by UV spectrophotometry.

Materials and methods. Chromatographic mobility of antidepressants in thin sorbent layers was studied in 11 mobile phases, including those recommended by TIAFT, using five types of chromatographic plates. A number of chromogenic reagents was used for visualization. The UV-spectrum of atomoxetine was studied in $0.1 \mathrm{Mol} \cdot \mathrm{L}^{-1}$ solution of hydrochloric acid.

Results and discussion. Chromatographic systems with the low correlation of $\mathrm{R}_{f}$ values for atomoxetine that make them suitable for the general TLC-screening have been found. The UV spectrum of atomoxetine in the acid solution had light absorption maxima at wavelengths of $270\left(\varepsilon=1300 ; \mathrm{A}_{1}^{1}=45\right)$ and $277 \mathrm{~nm}$.

Conclusions. A combined use of three mobile phases: methanol $-25 \%$ ammonia solution (100: 1.5), cyclohexane toluene - diethylamine (75:15:10), and toluene - acetone - $25 \%$ ammonia solution $(45: 45: 7.5: 2.5)$ provides a reliable atomoxetine detection in the presence of a number of its pharmacological and structural analogs when performing the general TLC-screening. The presence of specific light absorption in the UV region of the spectrum for atomoxetine makes the UV spectrophotometry method suitable for identification of the antidepressant in toxicological studies.

Key words: atomoxetine; TLC-screening; UV-spectrum

\section{Л. Ю. Томаровська, С. В. Баюрка, С. А. Карпушина}

Розробка методів ідентифрікації атомоксетину, придатних для хімікотоксикологічного аналізу

Зареєстровані випадки гострих та летальних отруєнь антидепресантом атомоксетином, тому розробка доступних і надійних методів його хіміко-токсикологічного аналізу є актуальною задачею.

Метою даних досліджень є розробка умов виявлення атомоксетину при при загальному ТШХ-скринінгу у присутності ряду його фрармакологічних і структурних аналогів та ідентифрікації антидепресанта методом УФспектрофотометрії.

Матеріали та методи. Хроматографічну рухливість антидепресантів у тонких шарах сорбенту досліджували в 11 рухомих фразах, зокрема рекомендованих TIAFT, на п'яти типах хроматографрічних пластин. Як візуалізатори використовували ряд хромогенних реактивів. УФ-спектр атомоксетину вивчали в $0,1 \mathrm{moль} \cdot \mathrm{\Omega}^{-1}$ розчині кислоти хлоридної.

Результати та їх обговорення. Встановлені хроматографрічні системи з низькою кореляцією величин $\mathrm{R}_{f}$ для атомоксетину і ряду його фармакологічних і структурних аналогів, що робить їх придатними для загального TШХ-скринінгу. УФ-спектр атомоксетину в розчині кислоти мав максимуми світлопоглинання при $270\left(\varepsilon_{\mathrm{m}}=1300\right.$; $\left.\mathrm{A}^{1 \%}{ }_{1 \mathrm{~cm}}=45\right)$ i $277 \mathrm{HM}$.

Висновки. Сумісне використання трьох рухомих фраз: метанол - 25 \% розчин амонію гідроксиду $(100: 1,5)$, циклогексан - толуен - діетиламін (75: $15: 10)$, толуен - ацетон - етанол - $25 \%$ розчин амонію гідроксиду (45: $45: 7,5: 2,5)$ забезпечує надійне виявлення атомоксетину при ТШХ-скринінгу у присутності ряду його фрармакологічних і структурних аналогів. Наявність для атомоксетину специфічного світлопоглинання в УФ-області спектра робить метод УФ-спектрофотометрії придатним для ідентифікації антидепресанта при токсикологічних дослідженнях.

Ключові слова: атомоксетин; ТШХ-скринінг; УФ-спектр

Л. Ю. Томаровская, С. В. Баюрка, С. А. Карпушина

Разработка методов идентификации атомоксетина, пригодных для химикотоксикологического анализа

Зарегистрированы случаи острых и летальных отравлений антидепрессантом атомоксетином, поэтому разработка доступных и надежных методов его химико-токсикологического анализа является актуальной задачей.

Целью данных исследований является разработка условий обнаружения атомоксетина при общем TCXскрининге в присутствии ряда его фрармакологических и структурных аналогов и идентификации антидепрессанта методом УФ-спектрофотометрии. 
Материалы и методы. Хроматографическую подвижность антидепрессантов в тонких слоях сорбента исследовали в 11 подвижных фазах, в том числе рекомендованных TIAFT, на пяти типах хроматографических пластин. Как визуализаторы использовали ряд хромогенных реактивов. УФ-спектр атомоксетина изучали в 0,1 моль $\cdot \pi^{-1}$ растворе кислоты хлоридной.

Результаты и их обсуждение. Установлены хроматографические системы с низкой корреляцией величин $\mathrm{R}_{f}$ для атомоксетина и ряда его фрармакологических и структурных аналогов, что делает их пригодными для общего ТСХ-скрининга. УФ-спектр атомоксетина в растворе кислоты имел максимумы светопоглощения при $270\left(\varepsilon_{\mathrm{m}}=1300 ; \mathrm{A}^{1 \%}{ }_{1 \mathrm{~cm}}=45\right)$ и $277 \mathrm{Hм}$.

Выводы. Совместное использование трех подвижных фраз: метанол - 25 \% раствор аммония гидроксида (100: 1,5), циклогексан - толуол - диэтиламин (75: $15: 10)$, толуол - ацетон - этанол - $25 \%$ раствор аммония гидроксида (45: $45: 7,5: 2,5)$ обеспечивает надежное обнаружение атомоксетина при ТСХ-скрининге в присутствии ряда его фармакологических и структурных аналогов. Наличие для атомоксетина специфического светопоглощения в УФ-области спектра делает метод УФ-спектрофотометрии пригодным для идентификации антидепрессанта при токсикологических исследованиях.

Ключевые слова: атомоксетин; ТСХ-скрининг; УФ-спектр

Atomoxetine is a thymoleptic from the group of selective norepinephrine reuptake inhibitors (central acting indirect sympathomimetic) [1] approved by the USA FDA in late 2002 [2]. It is used in the pharmacotherapy of attention deficit hyperactivity disorder [1], as well as in treatment-resistant depression, psychosis, bipolar disorders, epilepsy as an individual drug or as part of a complex treatment [3]. Unlike traditional psychostimulants, atomoxetine does not refer to narcotic substances and shows no abuse potential associated with them [4].

Atomoxetine has some side effects [1,5], among them the appearance of suicide thoughts is the most serious complication [6]. This drug is incompatible with monoamine oxidase inhibitors [7].

The cases of chronic overdose and acute and lethal poisoning by atomoxetine were registered $[8,9]$. The literature review revealed [9] that postmortem atomoxetine concentrations were within the following limits: arterial blood $-0.1-8.3 \mathrm{mg} \cdot \mathrm{L}^{-1}$; femoral blood $-0.33-5.4 \mathrm{mg} \cdot \mathrm{L}^{-1}$; vitreous body $-0.1-0.96 \mathrm{mg} \cdot \mathrm{L}^{-1}$; bile $-1.0-33 \mathrm{mg} \cdot \mathrm{L}^{-1}$; urine $-0.1 \mathrm{mg} \cdot \mathrm{L}^{-1}$; liver $-0.44-29 \mathrm{mg} \cdot \mathrm{kg}^{-1}$; stomach contents $-0.0097-16.8 \mathrm{mg}$ in the sample studied.

Most bioanalytical methods described in the literature for atomoxetine determination are based on using HPLC with different types of detection: UV [10,11, 12], mass spectrometry (MS) [13, 14] fluorescence [15] or capillary electrophoresis [16]. These methods of analysis are not always available for toxicological laboratories; they require expensive equipment and the appropriate skill level of the staff.

The combination of TLC during the toxicological screening and absorption spectrophotometry in the UV region for the confirmatory study is an available approach for use in the chemical and toxicological analysis [17, 18]. Information on using TLC and UV spectrophotometry for detection and identification of atomoxetine has not been found in the available literature.

The aim of the study was to develop the conditions for atomoxetine detection in the presence of a number of its pharmacological and structural analogs when performing the general TLC-screening and the antidepressant identification by UV spectrophotometry.

\section{Materials and methods}

The pure substance of atomoxetine isolated from the medicine "Strattera" (7 capsules, $60 \mathrm{mg}$ ) produced by "Lilly" (Czech Republic) was used for the study.

Extraction of the atomaxetine substance from capsules. Triturate the content of 7 capsules in a porcelain mortar, add $50 \mathrm{~mL}$ of absolute ethanol, and then filter the mixture through a folded filter paper in a porcelain evaporating dish. Wash the residue on the filter once with $20 \mathrm{~mL}$ of absolute ethanol, and combine the ethanol filtrates. Evaporate the dish content on a water bath at $40-60{ }^{\circ} \mathrm{C}$ to complete removal of the organic solvent. Dry the residue in the loss-on-drying oven and weigh.

Using this method $400 \mathrm{mg}$ of atomoxetine hydrochloride was obtained. The purity of the substance was tested by TLC, UV spectrophotometry and HPLC, and its compliance with the quality requirements of the $\mathrm{SPhU}$ was determined.

All other chemicals were of analytical grade or better.

Chromatographic plates manufactured in Estonia (the sorbent $-\mathrm{KSKG}$, the fraction $-5 \div 20 \mu \mathrm{m}$, its thickness $-130 \pm 25 \mu \mathrm{m}$, the plate size $-20 \times 20 \mathrm{~cm})(\mathrm{I})$, Sorbfil (silica gel CTX-1 VE, PET substrate, silica sol as a binder, the fraction $-8 \div 12 \mu \mathrm{m}$, its thickness $-100 \mu \mathrm{m}$, the plate size $-10 \times 10 \mathrm{~cm}$ ) (II), Silufol UV-254 (sorbent Silpearl with a luminescent indicator for UV 254 on the aluminium foil, starch as a binder, the plate size $10 \times 10 \mathrm{~cm}$ ) (III), Armsorb (TLC KSKG, the thickness $100 \pm 10 \mu \mathrm{m}$, the plate size $-5 \times 15 \mathrm{~cm}$ ) (IV), Merck (Silica gel $60 \mathrm{~F} 254$, the size $-10 \times 20 \mathrm{~cm}$, Germany) (V) were used.

The TLC ultraviolet lamp was $254 / 365 \mathrm{~nm}$.

The following glassware was used: $10.0 \mathrm{~mL}, 50.0 \mathrm{~mL}$ volumetric flasks, volumetric pipettes, Class A (Simax, Czech Republic).

In the study the water bath LW-4 (Bytom, Poland) and a spectrophotometer (SF-46, LOMO, USSR) with the spectral measurement range of $190-1100 \mathrm{~nm}$ were also applied.

Developers recommended by the Committee of Systematic Toxicological Analysis of the International Association of Forensic Toxicologists (TIAFT) for the ge- 
neral TLC-screening $[17,18]$, and reagents proposed by the WHO and the UNO [19] to identify the main groups of potent substances (Tab. 1) were studied as chromogenic reagents. According to the recommendations of UNODC [20] determination 10 samples containing the drug from 1.25 - LOD to $2.0 \cdot$ LOD were studied to determine the limit of detection (LOD). The number of false negative results was not more than 2 out of 10 experiments (RSD $\leq 20 \%)$.

Chromogenic reagents were prepared as follows [17, 18].

Preparation of stock solution (SS) and working standard solutions (WSS) of atomoxetine hydrochloride. Dissolve $0.02190 \mathrm{~g}$ of atomoxetine hydrochloride in $50.0 \mathrm{~mL}$ of $0.1 \mathrm{Mol} \cdot \mathrm{L}^{-1}$ hydrochloric acid using a $50.0 \mathrm{~mL}$ volumetric flask (the concentration of the resulting SS was $1.5 \cdot 10^{-3} \mathrm{Mol} \cdot \mathrm{L}^{-1}$ of atomoxetine hydrochloride). Place $0.50 ; 1.00 ; 2.00 \mathrm{~mL}$ of SS into a $10.0 \mathrm{~mL}$ volumetric flask and dilute to the volume with $0.1 \mathrm{Mol} \cdot \mathrm{L}^{-1}$ hydrochloric acid (the concentrations of the resulting WSS were of $0.75 \cdot 10^{-4} ; 1.5 \cdot 10^{-4} ; 3 \cdot 10^{-4} \mathrm{Mol} \cdot \mathrm{L}^{-1}$ of atomoxetine hydrochloride).

The method of atomoxetine chromatographic mobility determination in thin sorbent layers. Spot $10-\mu \mathrm{L}$ aliquots of ethanol solutions (the concentration of $\left.2 \mathrm{mg} \cdot \mathrm{mL}^{-1}\right)$ of atomoxetine and other antidepressants under study (venlafaxine, fluoxetine, fluvoxamine, amitriptyline, melipramine and doxepin) with the help of a calibrated glass capillary at the starting line of the chromatographic plate of the corresponding type at a distance of $2 \mathrm{~cm}$ from each side. Place the chromatographic plate into a $1.000 \mathrm{~cm}^{3}$ chromatographic chamber containing $20 \mathrm{~mL}$ of the corresponding mobile phase (m. ph.). The list of mobile phases is shown in Tab. 2. Saturate the chamber for $15 \mathrm{~min}$ (do not saturate the chamber when using m.ph. No. 1, 5). When using m.ph. No. 3, 7, 8, 9 pre-treat Merck chromatographic plates with $0.1 \mathrm{Mol} \cdot \mathrm{L}^{-1} \mathrm{KOH}$ solution in methanol and dry.

Detection was performed under UV rays and by Dragendorff - Munier reagent.

The method for performing reactions with chromogenic reagents. Spot the corresponding volumes of ethanol solutions of atomoxetine, venlafaxine, fluoxetine, fluvoxamine, amitriptyline, melipramine and doxepin $\left(1.0 \mathrm{mg} \cdot \mathrm{mL}^{-1}\right)$ on a chromatographic plate using a calibrated glass capillary, obtaining samples with the antidepressant content from 0.2 to $20.0 \mu \mathrm{g}$ of the drug in the spot. Treat the samples with chromogenic reagents, determine the sensitivity and color of the reaction products (Tab. 1).

The study of UV-spectra of atomoxetine. The WSS of atomoxetine with the concentrations of $0.75 \cdot 10^{-4}$; $1.5 \cdot 10^{-4}$ and $3 \cdot 10^{-4} \mathrm{Mol} \cdot \mathrm{L}^{-1}$ in $0.1 \mathrm{Mol} \cdot \mathrm{L}^{-1}$ of hydrochloric acid were studied to obtain the optimal absorbance values corresponding to the absorbance range of 0.1 to 1.0 absorbance units. The UV-spectra were measured in the range of $210-380 \mathrm{~nm}$ in a $10 \mathrm{~mm}$ light pathway cuvette. The reference solution was $0.1 \mathrm{Mol} \cdot \mathrm{L}^{-1}$ hydrochloric acid.

\section{Results and discussion}

Chromatographic mobility of atomoxetine, venlafaxine, fluoxetine, fluvoxamine, amitriptyline, melipramin and doxepin in thin sorbent layers were studied in the m. ph. recommended by TIAFT for the general TLCscreening of drugs (m.ph. No. 1-9) $[17,18]$ and in the $\mathrm{m}$.ph. widely used in the national practice of forensic toxicological studies (m. ph. No. 10, 11) [21, 22]. The $\mathrm{Rf}$ values of atomoxetine, venlafaxine, fluoxetine, fluvoxamine, amitriptyline, melipramine and doxepin are shown in Tab. 2.

Atomoxetine exhibited $R_{f}$ values acceptable for identification in m.ph. No. $4,7,8,10,11$. In m. ph. No. 7 separation of all antidepressants under study was observed. The use of m.ph. No. 8 gave the possibility of appropriate separation of atomoxetine from other drugs under study, excluding fluoxetine and fluvoxamine. In the mobile phase mentioned atomoxetine, fluoxetine and fluvoxamine showed the low correlation of $\mathrm{R} f$ values compared to m.ph. No. 7. Separation of atomoxetine from other antidepressants studied, with the exception of fluoxetine, was also observed in m.ph. No. 10. Moreover, in the m.ph. No. 10 atomoxetine and fluoxetine had the inverse correlation of chromatographic mobility compared to m.ph. No. 7. It greatly increases the reliability of identification of these antidepressants. Therefore, the use of three m.ph. No. 7, 8 and 10 are recommended for atomoxetine identification in the presence of a number of its structural and pharmacological analogs when performing TLC-screening. According to the TIAFT recommendations the use of several chromatographic systems preferably with the low correlation of $\mathrm{R} f$ values significantly increases the reliability for identification of substances by TLC $[17,18]$.

The UV-light and Dragendorff reagent with Munier modification were the most sensitive for detecting atomoxetine and other antidepressants studied. For atomoxetine LOD was $0.3 \mu \mathrm{g}$ in the sample in UV light at $254 \mathrm{~nm}$, and $0.5 \mu \mathrm{g}$ in the sample at $365 \mathrm{~nm}$ using Dragendorff reagent with Munier modification. High sensitivity compared to atomoxetine also was found when using Froehde reagent (1.0 $\mu \mathrm{g}$ in the sample), which formed products of a blue color with the antidepressant. Thus, Froehde reagent can be recommended as a relatively selective reagent to biological admixtures for detection of atomoxetine in biological extracts. Melipramine and doxepin also formed blue coloration with Froehde reagent. But they did not give color with Marquis reagent, a pink color was observed under its action on atomoxetine.

Antidepressants containing in its structure the secondary (atomoxetine, venlafaxine, fluoxetine) or primary (fluvoxamine) amino group with ninhydrin solution gave intense coloration with different colors. Specific color transitions were observed while processing of atomoxetine spots with Mandelin reagent and formaldehyde vapor consequentially (modified Mandelin reagent) (Tab. 1).

Thus, when performing the TLC-screening for detection and identification of atomoxetine in the presence of its structural and pharmacological analogs (venlafaxine, fluoxetine, fluvoxamine, amitriptyline, melipramine and doxepin) it is appropriate to use chromogenic reagents in the following sequence: UV light, ninhydrin solution, Dragendorff reagent (it can be used after 
䒿

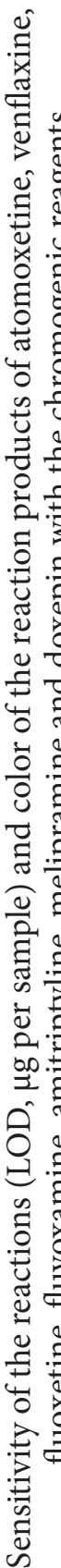

\begin{tabular}{|c|c|c|c|c|c|c|c|c|}
\hline & 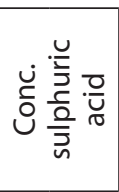 & 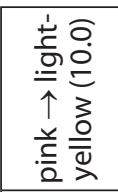 & 巳্ & 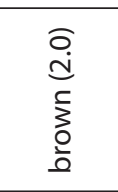 & نே & $\stackrel{\stackrel{\leftrightarrow}{\check{~}}}{ }$ & ن् & 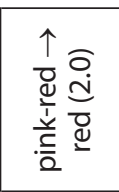 \\
\hline & $\underset{\text { ż }}{z}$ & نُ & نب & $\stackrel{\infty}{\stackrel{\infty}{\leftrightarrows}}$ & 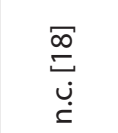 & 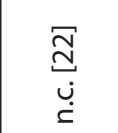 & نُ & 巳্் \\
\hline & $\begin{array}{l}\frac{0}{\frac{0}{d}} \\
\frac{0}{0} \\
\frac{0}{4}\end{array}$ & $\begin{array}{l}\bar{\partial} \\
\stackrel{\bar{\Xi}}{0} \\
\frac{o}{0}\end{array}$ & 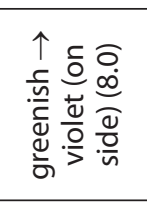 & $\begin{array}{l}\frac{\partial}{\dot{d}} \\
\frac{a}{0} \\
\frac{\partial}{0}\end{array}$ & ب্ & 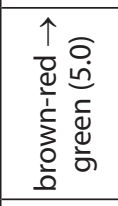 & $\begin{array}{l}\frac{a}{d} \\
\stackrel{d}{0} \\
\frac{0}{0}\end{array}$ & 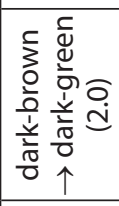 \\
\hline & 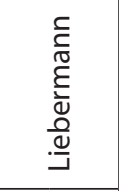 & 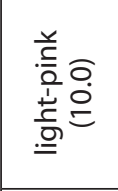 & 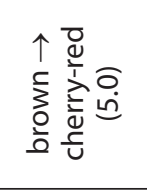 & 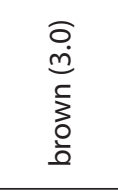 & 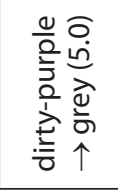 & 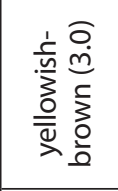 & 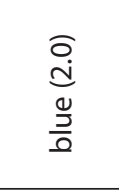 & 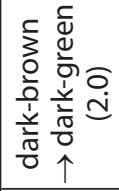 \\
\hline & 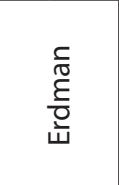 & 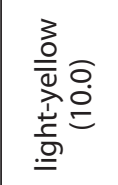 & 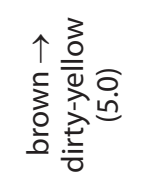 & بٌ & ب্ & $\stackrel{\stackrel{\leftrightarrow}{\Xi}}{ }$ & نُ & 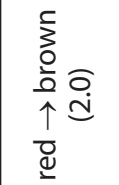 \\
\hline 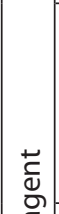 & 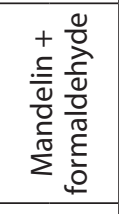 & 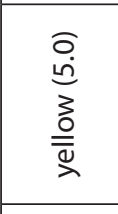 & 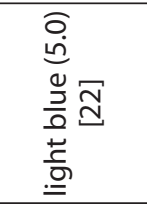 & 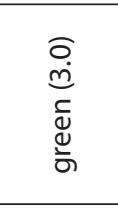 & 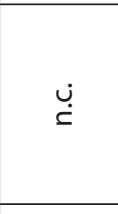 & 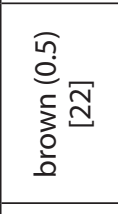 & $\begin{array}{l}0 \\
\stackrel{0}{0} \\
\stackrel{0}{0} \\
\frac{0}{0}\end{array}$ & 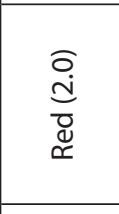 \\
\hline \begin{tabular}{|l|}
$\mathbb{\pi}$ \\
$\widetilde{\Psi}$
\end{tabular} & 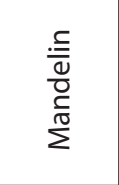 & 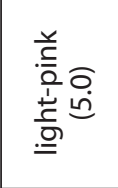 & 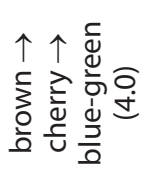 & 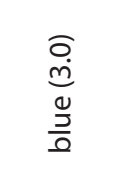 & $\stackrel{\stackrel{\leftrightarrow}{\leftrightarrows}}{ }$ & 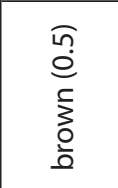 & $\begin{array}{l}\overline{0} \\
\stackrel{0}{0} \\
\frac{0}{0} \\
\frac{0}{0}\end{array}$ & 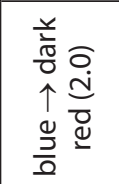 \\
\hline & $\begin{array}{l}\frac{n}{\overline{5}} \\
\frac{0}{\frac{0}{\pi}}\end{array}$ & 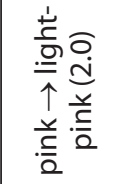 & 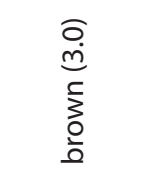 & نُ & بٌ & 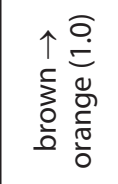 & نُ & 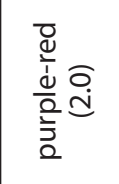 \\
\hline & 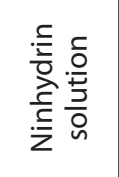 & 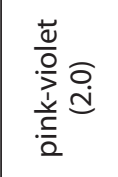 & 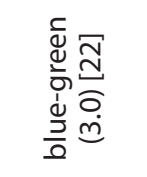 & 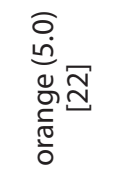 & 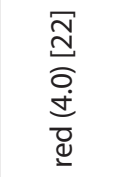 & $\stackrel{\stackrel{\infty}{\leftrightarrows}}{\stackrel{\infty}{\check{c}}}$ & 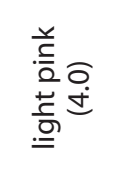 & 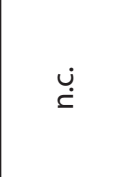 \\
\hline & 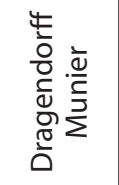 & $\begin{array}{l}\pi n \\
0 \\
0 \\
0 \\
0 \\
0 \\
0\end{array}$ & 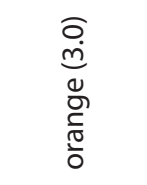 & $\begin{array}{l}\sqrt{n} \\
0 \\
0 \\
0 \\
\frac{0}{0} \\
0\end{array}$ & 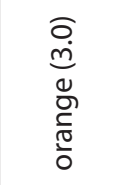 & 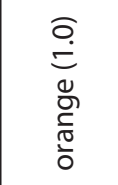 & 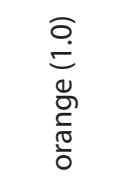 & $\begin{array}{l}\text { חొ } \\
\stackrel{0}{0} \\
0 \\
\stackrel{0}{\pi} \\
0\end{array}$ \\
\hline & 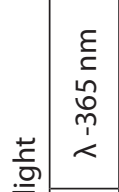 & 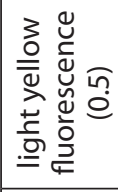 & 悉: & 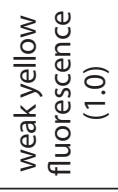 & 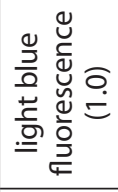 & 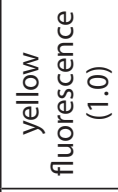 & 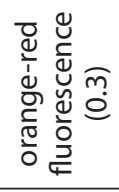 & $\stackrel{4}{\dot{E}}$ \\
\hline & 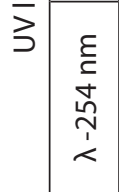 & 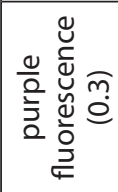 & 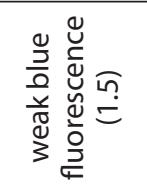 & 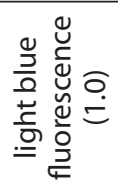 & 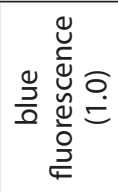 & 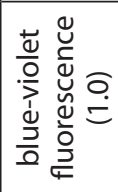 & 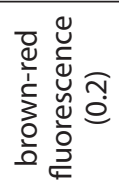 & 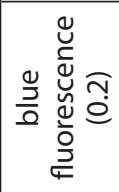 \\
\hline & 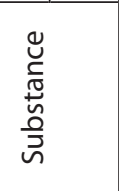 & 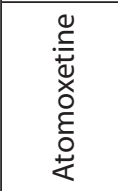 & 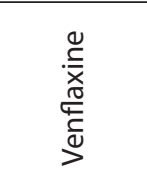 & 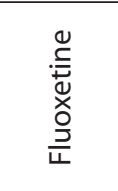 & 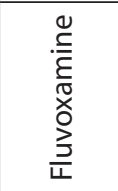 & 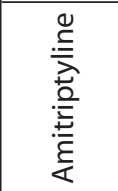 & 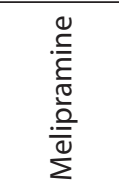 & 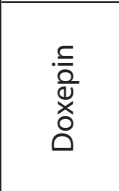 \\
\hline
\end{tabular}




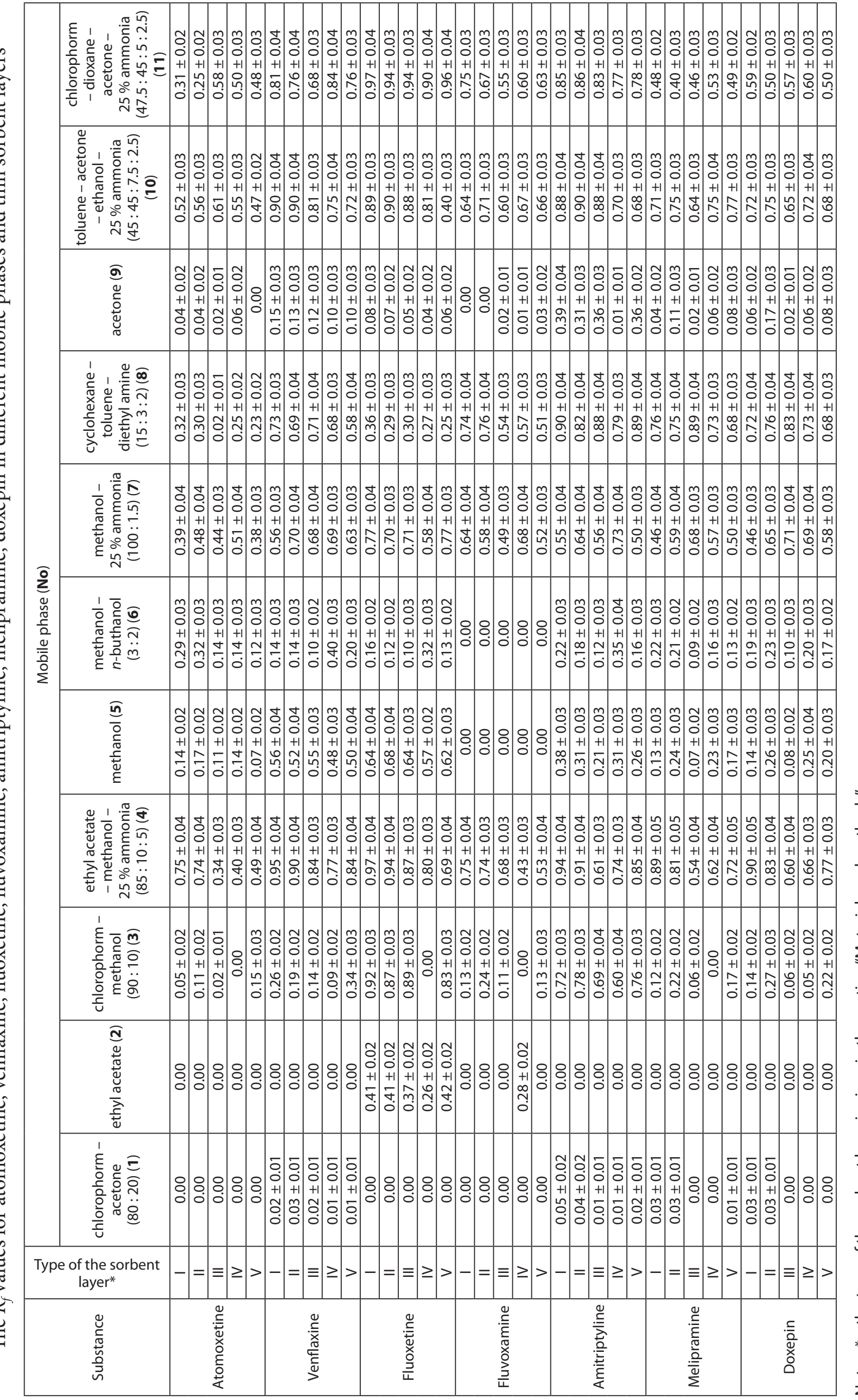




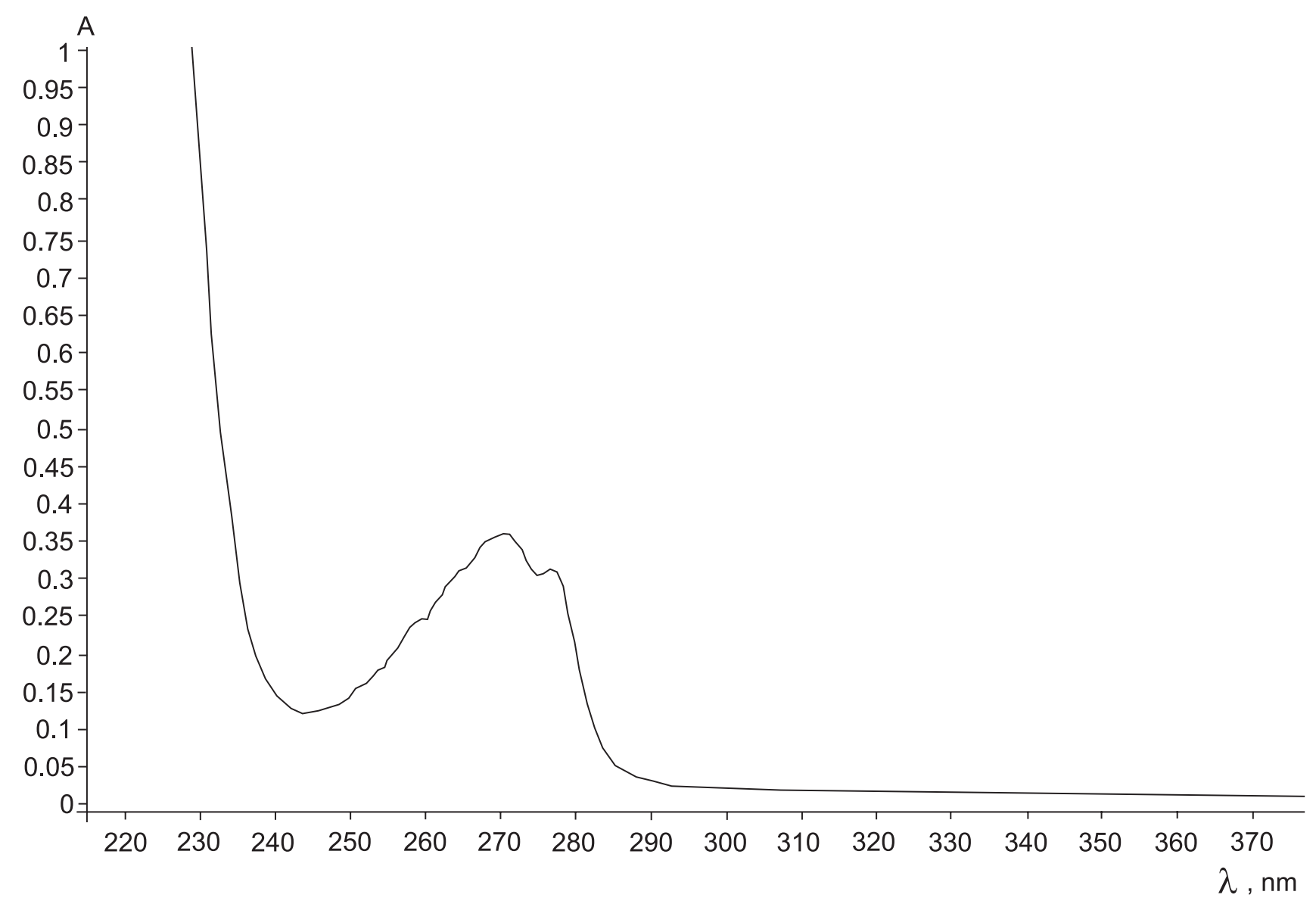

Fig. The UV-spectrum of atomoxetine in $0.1 \mathrm{Mol} \cdot \mathrm{L}^{-1}$ hydrochloric acid solution (the concentration of $3 \cdot 10^{-4} \mathrm{Mol} \cdot \mathrm{L}^{-1}$ )

pre-treatment of spots with ninhydrin), Froedhe reagent, Marquis reagent, modified Mandelin reagent. According to the TIAFT recommendations on the reliable identification of toxic substances in TLC-screening the acceptable condition is to use at least four reagents on the same chromatographic plate consequentially $[17,18]$.

While conducting the TLC-screening simultaneously the separation of the substances studied from the components of the biological matrix (TLC purification) occurs, and it is a prerequisite for the use of UV spectrophotometry to identify the toxic substance at the confirmation stage of toxicological studies.

The UV-spectrum of atomoxetine in $0.1 \mathrm{Mol} \cdot \mathrm{L}^{-1}$ hydrochloric acid solution was studied, and the presence of specific absorption was determined (Fig.). The molar absorptivity $\left(\varepsilon_{\mathrm{v}}\right)$ and the specific absorption coefficient $\left(\mathrm{A}_{1}{ }_{1}\right)$ for the higher intensity absorption peak at $270 \mathrm{~nm}$ were calculated using the absorbance values of three WSS given above. Absorption maxima for atomoxetine solutions in $0.1 \mathrm{~mol} \cdot \mathrm{L}^{-1}$ hydrochloric acid $\left(\lambda_{\max } \pm 2\left(\varepsilon_{\mathrm{v}} ; \mathrm{A}^{1}{ }_{1}\right)\right)$ were observed at the wavelengths of $270(1,300 ; 45)$ and $277 \mathrm{~nm}$.

\section{CONCLUSIONS}

1. The parameters of chromatographic mobility of atomoxetine and a number of its structural and pharmacological analogs (venlafaxine, fluoxetine, fluvoxamine, amitriptyline, melipramine and doxepin) have been determined in thin sorbent layers using mobile phases recom- mended by TIAFT for the general TLC-screening and mobile phases, which are widely used in toxicological screening of the basic drugs. Chromatographic mobility has been studied using five types of chromatographic plates.

2. It has been found that the combined use of three mobile phases: methanol $-25 \%$ ammonia solution $(100$ : $1.5)$, cyclohexane - toluene - diethylamine $(75: 15: 10)$, toluene - acetone $-25 \%$ ammonia solution $(45: 45$ : $7.5: 2.5)$ is the most acceptable for atomoxetine detection in the presence of a number of its pharmacological and structural analogs when performing the general TLC-screening.

3. Sensitive and specific chromogenic reagents for atomoxetine identification in the presence of a number of its structural and pharmacological analogs have been determined. It has been recommended to use the chromogenic reagents in the following sequence: UV light, ninhydrin solution, Dragendorff reagent, Froedhe reagent, Marquis reagent, modified Mandelin reagent.

4. The presence of specific light absorption in the UV region of the spectrum for atomoxetine solution in $0.1 \mathrm{Mol} \cdot \mathrm{L}^{-1}$ hydrochloric acid at $270\left(\varepsilon_{\mathrm{m}}=1,300 ; \mathrm{A}_{1}^{1}=45\right)$ and $277 \mathrm{~nm}$ has been found, it makes the UV spectrophotometry method suitable for identifying the antidepressant in toxicological studies.

Conflict of Interests: authors have no conflict of interests to declare. 


\section{REFERENCES}

1. Garnock-Jones, K. P. Atomoxetine : a review of its use in attention-deficit hyperactivity disorder in children and adolescents / K. P. GarnockJones, G. M. Keating // Paediatr. Drugs. - 2009. - Vol. 11, Issue 3. - P. 203-226. doi: 10.2165/00148581-200911030-00005

2. Childress, A. C. A critical appraisal of atomoxetine in the management of ADHD / A. C. Childress // Ther. Clin. Risk Manag. - 2015. Vol. 12. - 27 p. doi: $10.2147 /$ tcrm.s59270

3. A systematic review of combination therapy with stimulants and atomoxetine for attention-deficit/hyperactivity disorder, including patient characteristics, treatment strategies, effectiveness, and tolerability / T. Treuer, S. S. Gau, L. Méndez et al. // J. Child Adolesc. Psychopharmacol. - 2013. - Vol. 23, Issue 3. - P. 179-193. doi: 10.1089/cap.2012.0093

4. Párraga, H. C. Tic exacerbation and precipitation during atomoxetine treatment in two children with attention-deficit hyperactivity disorder / H. C. Párraga, M. I. Párraga, D. K. Harris // Int. J. Psychiatry Med. - 2007. - Vol. 37, Issue 4. - P. 415-424. doi: 10.2190/ pm.37.4.e

5. Kasi, P. M. Cardiovascular side effects of atomoxetine and its interactions with inhibitors of the cytochrome P450 system / P. M. Kasi, R. Mounzer, G. H. Gleeson // Case. Rep. Med. - 2011. - Vol. 2011. - P. 1-3. doi: 10.1155/2011/952584

6. Paxton, G. A. Acute suicidality after commencing atomoxetine / G. A. Paxton, N. E. Cranswick // J. Paediatr. Child Health. - 2008. Vol. 44, Issue 10. - P. 596-598. doi: 10.1111/j.1440-1754.2008.01389.x

7. Lynch, T. Atomoxetine for ADHD / T. Lynch // Am. Fam. Physician. - 2003. - Vol. 68, Issue 9. - P. 1827-1828.

8. The Safety of Atomoxetine for the Treatment of Children and Adolescents with Attention-Deficit/Hyperactivity Disorder : A Comprehensive Review of Over a Decade of Research / V. A. Reed, J. K. Buitelaar, E. Anand et al. // CNS Drugs. - 2016. - Vol. 30, Issue 7. P. 603-628. doi: 10.1007/s40263-016-0349-0

9. Garside, D. Postmortem tissue distribution of atomoxetine following fatal and nonfatal doses - three case reports / D. Garside, J. D. RoperoMiller, E. C. Riemer // J. Forensic Sci. - 2006. - Vol. 51, Issue 1. - P. 179-182. doi: 10.1111/j.1556-4029.2005.00021.x

10. A new high performance liquid chromatographic method for quantification of atomoxetine in human plasma and its application for pharmacokinetic study / C. Patel, M. Patel, S. Rani et al. // J. Chromatogr. B Analyt. Technol. Biomed. Life Sci. - 2007. - Vol. 850, Issue 1-2. P. 356-360. doi: 10.1016/j.jchromb.2006.12.011

11. Determination of atomoxetine in human plasma by a high performance liquid chromatographic method with ultraviolet detection using liquid-liquid extraction / W. Guo, W. Li, G. Guo et al. // J. Chromatogr. B Analyt. Technol. Biomed. Life Sci. - 2007. - Vol. 854, Issue 1-2. P. 128-134. doi: 10.1016/j.jchromb.2007.04.007

12. Relative bioequivalence evaluation of two oral atomoxetine hydrochloride capsules : a single dose, randomized, open-label, 2-period crossover study in healthy Chinese volunteers under fasting conditions / D. W. Shang, W. Guo, F. C. Zhou et al. // Drug Res. (Stuttg.). 2013. - Vol. 63, Issue 11. - P. 564-567. doi: 10.1055/s-0033-1349070

13. Simultaneous quantification of atomoxetine as well as its primary oxidative and O-glucuronide metabolites in human plasma and urine using liquid chromatography tandem mass spectrometry (LC/MS/MS) / J. H. Mullen, R. L. Shugert, G. D. Ponsler et al. // J. Pharm. Biomed. Anal. - 2005. - Vol. 38, Issue 4. - P. 720-733. doi: 10.1016/j.jpba.2005.02.007

14. A liquid chromatography/tandem mass spectrometry assay for the analysis of atomoxetine in human plasma and in vitro cellular samples / D. I. Appel, B. Brinda, J. S. Markowitz et al. // Biomed. Chromatogr. - 2012. - Vol. 26, Issue 11. - P. 1364-1370. doi: 10.1002/bmc.2706

15. Sensitive quantification of atomoxetine in human plasma by HPLC with fluorescence detection using 4-(4,5-diphenyl-1H-imidazole-2-yl) benzoyl chloride derivatization / H. J. Zhu, J. S. Wang, J. L. Donovan et al. // J. Chromatogr. B Analyt. Technol. Biomed. Life Sci. - 2007. - Vol. 846, Issue 1-2. - P. 351-354. doi: 10.1016/j.jchromb.2006.08.019

16. Capillary electrophoresis coupled with electrochemiluminescence for determination of atomoxetine hydrochloride and the study on its interactions with three proteins / H. J. Zeng, R. Yang, Y. Zhang et al. // Luminescence. - 2015. - Vol. 30, Issue 2. - P. 124-130. doi: $10.1002 /$ bio. 2700

17. Clarke's Analytical Forensic Toxicology / ed. by Sue Jickells, Adam Negrusz. - London : Pharmaceutical Press, 2008. - 648 p.

18. Clarke's analysis of drugs and poisons in pharmaceuticals, body fluids and postmortem material : 4-th ed. / ed. by A. C. Moffat, M. D. Osselton, B. Widdop. - London, Chicago : Pharmaceutical Press, 2011. - 2736 p.

19. Rapid Testing Methods of Drugs of Abuse : Manual for Use by National Law Enforcement and Narcotic Laboratory Personnel. - United Nations : Office on Drugs and Crime, 2008. - $111 \mathrm{p}$.

20. Guidance for the Validation of Analytical Methodology and Calibration of Equipment used for Testing of Illicit Drugs in Seized Materials and Biological Specimens. - New York, 2009. - 67 p.

21. Хіжніченко, О.В.Хіміко-токсикологічне дослідження нових лікарських засобів - потенційних об’єктів немедичного використання методом хроматографії у тонких шарах сорбенту / О. В. Хіжніченко, Н. В. Гузенко, О. В. Чубенко // Фармац. журн. - 2011. № 6. - С. 74-78.

22. Баюрка, С. В. Розробка методів хіміко-токсикологічного аналізу лікарських речовин антидепресивної дії : дис. ... д. фарм. наук / С. В. Баюрка. - X., 2016. - 547 с.

\section{REFERENCES}

1. Garnock-Jones, K. P., Keating, G. M. (2009). Atomoxetine: a review of its use in attention-deficit hyperactivity disorder in children and adolescents. Pediatric Drugs, 11 (3), 203-226. doi: 10.2165/00148581-200911030-00005

2. Childress, A. C. (2015). A critical appraisal of atomoxetine in the management of ADHD. Therapeutics and Clinical Risk Management, 12, 27. doi: 10.2147/TCRM.S59270

3. Treuer, T., Gau, S. S.-F., Méndez, L., Montgomery, W., Monk, J. A., Altin, M., Dueñas, H. J. (2013). A Systematic Review of Combination Therapy with Stimulants and Atomoxetine for Attention-Deficit/Hyperactivity Disorder, Including Patient Characteristics, Treatment Strategies, Effectiveness, and Tolerability. Journal of Child and Adolescent Psychopharmacology, 23 (3), 179-193. doi:10.1089/ cap. 2012.0093 
4. Párraga, H. C., Párraga, M. I., Harris, D. K. (2007). Tic Exacerbation and Precipitation during Atomoxetine Treatment in Two Children with Attention-Deficit Hyperactivity Disorder. The International Journal of Psychiatry in Medicine, 37 (4), 415-424. doi: 10.2190/pm.37.4.e

5. Kasi, P. M., Mounzer, R., Gleeson, G. H. (2011). Cardiovascular side effects of atomoxetine and its interactions with inhibitors of the cytochrome P450 system. Case reports in medicine, 2011, 1-3. doi: 10.1155/2011/952584

6. Paxton, G. A., Cranswick, N. E. (2008). Acute suicidality after commencing atomoxetine. Journal of Paediatrics and Child Health, 44 (10), 596-598. doi: 10.1111/j.1440-1754.2008.01389.x

7. Lynch, T. (2003). Atomoxetine for ADHD. American Family Physician, 68 (9), 1827-1828.

8. Reed, V. A., Buitelaar, J. K., Anand, E., Day, K. A., Treuer, T., Upadhyaya, H. P., Savill, N. C. (2016). The Safety of Atomoxetine for the Treatment of Children and Adolescents with Attention-Deficit/Hyperactivity Disorder: A Comprehensive Review of Over a Decade of Research. CNS drugs, 30 (7), 603-628. doi: 10.1007/s40263-016-0349-0

9. Garside, D., Ropero-Miller, J. D., Riemer, E. C. (2006). Postmortem Tissue Distribution of Atomoxetine Following Fatal and Nonfatal Doses-Three Case Reports. Journal of Forensic Sciences, 51 (1), 179-182. doi: 10.1111/j.1556-4029.2005.00021.x

10. Patel, C., Patel, M., Rani, S., Nivsarkar, M., Padh, H. (2007). A new high performance liquid chromatographic method for quantification of atomoxetine in human plasma and its application for pharmacokinetic study. Journal of Chromatography B, 850 (1-2), 356-360. doi: 10.1016/j.jchromb.2006.12.011

11. Guo, W., Li, W., Guo, G., Zhang, J., Zhou, B., Zhai, Y., Wang, C. (2007). Determination of atomoxetine in human plasma by a high performance liquid chromatographic method with ultraviolet detection using liquid-liquid extraction. Journal of Chromatography B, 854 (1-2), 128-134. doi: 10.1016/j.jchromb.2007.04.007

12. Shang, D. W., Guo, W., Zhou, F. C., Wang, X. P., Li, A. N., Zhang, L., Wang, C. Y. (2013). Relative bioequivalence evaluation of two oral atomoxetine hydrochloride capsules: a single dose, randomized, open-label, 2-period crossover study in healthy Chinese volunteers under fasting conditions. Drug Research, 63 (11), 564-567. doi: 10.1055/s-0033-1349070

13. Mullen, J. H., Shugert, R. L., Ponsler, G. D., Li, Q., Sundaram, B., Coales, H. L., Sauer, J.-M. (2005). Simultaneous quantification of atomoxetine as well as its primary oxidative and $\mathrm{O}-$ glucuronide metabolites in human plasma and urine using liquid chromatography tandem mass spectrometry (LC/MS/MS). Journal of Pharmaceutical and Biomedical Analysis, 38 (4), 720-733. doi: 10.1016/j. jpba.2005.02.007

14. Appel, D. I., Brinda, B., Markowitz, J. S., Newcorn, J. H., Zhu, H. J. (2012). A liquid chromatography/tandem mass spectrometry assay for the analysis of atomoxetine in human plasma and in vitro cellular samples. Biomedical Chromatography, 26 (11), $1364-1370$. doi: $10.1002 / b m c .2706$

15. Zhu, H.-J., Wang, J.-S., Donovan, J. L., DeVane, C. L., Gibson, B. B., Markowitz, J. S. (2007). Sensitive quantification of atomoxetine in human plasma by HPLC with fluorescence detection using 4-(4,5-diphenyl-1H-imidazole-2-yl) benzoyl chloride derivatization. Journal of Chromatography B, 846 (1-2), 351-354. doi: 10.1016/j.jchromb.2006.08.019

16. Zeng, H. J., Yang, R., Zhang, Y., Li, J. J., Qu, L. B. (2015). Capillary electrophoresis coupled with electrochemiluminescence for determination of atomoxetine hydrochloride and the study on its interactions with three proteins. Luminescence, 30 (2), $124-130$. doi: 10.1002/bio.2700

17. Jickells, S., Negrusz, A. (2008). Clarke’s Analytical Forensic Toxicology. London: Pharmaceutical Press, 648.

18. Moffat, A. C., Osselton, M. D., Widdop, B., Clarke, E. G. C. (2011). Clarke's analysis of drugs and poisons in pharmaceuticals, body fluids and postmortem material. (4-th ed.). London, Chicago: Pharmaceutical Press, 2736.

19. Rapid Testing Methods of Drugs of Abuse: Manual for Use by National Law Enforcement and Narcotic Laboratory Personnel. (2008). United Nations Office on Drugs and Crime. New York, 111.

20. Guidance for the Validation of Analytical Methodology and Calibration of Equipment used for Testing of Illicit Drugs in Seized Materials and Biological Specimens.(2009). United Nations Office on Drugs and Crime. New York, 67.

21. Khizhnichenko, O. V., Huzenko, N. V., Chubenko, O. V. (2011). Farmatsevtychnyi zhurnal, 6, 74-78.

22. Baiurka, S. V. (2016). Rozrobka metodiv khimiko-toksykolohichnoho analizu likarskykh rechovyn antydepresyvnoi dii. Kharkiv, 547.

Information about authors:

Tomarovska L. Yu., teaching assistant of the Physical and Colloid Chemistry Department, National University of Pharmacy. E-mail: 10639584807@gmail.com

Baiurka S. V., Doctor of Pharmacy (Dr. habil.), associate professor of the Drug and Analytical Toxicology Department, National University of Pharmacy.

E-mail: bayurka.sergii@gmail.com

Karpushyna S. A., Candidate of Chemistry (Ph.D.), associate professor of the Drug and Analytical Toxicology Department, National University of Pharmacy.

E-mail: svitkrp@gmail.com

Відомості про авторів:

Томаровська Л. Ю., асистент кафедри фізичної та колоїдної хімії, Національний фармацевтичний університет. E-mail: 10639584807@gmail.com

Баюрка С. В., д-р фармац. наук, доцент, завідувач кафедри лікарської та аналітичної токсикології, Національний фармацевтичний університет.

E-mail: bayurka.sergii@gmail.com

Карпушина С. А., канд. хім. наук, доцент кафедри лікарської та аналітичної токсикології, Національний фармацевтичний університет.

E-mail: svitkrp@gmail.com

Сведения об авторах:

Томаровская Л. Ю., ассистент кафедры физической и коллоидной химии, Национальный фармацевтический университет. Е-таil: 10639584807@gmail.сот

Баюрка С. В., д-р фармац. наук, доцент, заведующий кафедрой лекарственной и аналитической токсикологии, Национальный фармацевтический

университет. E-mail: bayurka.sergii@gmail.com

Карпушина С. А., канд. хим. наук, доцент кафедры лекарственной и аналитической токсикологии, Национальный фармацевтический университет.

E-mail: svitkrp@gmail.com 